Management international

International Management

Gestiòn Internacional

Antecedents of Female Representation on Corporate Boards: An Exploratory Analysis at Board Level from a Socialized Perspective Antécédents de la représentation féminine dans les conseils d'administration : analyse exploratoire au niveau des conseils d'administration dans une perspective socialisée Antecedentes de la representación femenina en juntas ejecutivas: análisis exploratorio a nivel de juntas desde una perspectiva socializada

Rey Dang, L’Hocine Houanti, Frédéric Teulon et Linh-Chi Vo

Volume 23, numéro hors-série, 2019

URI : https://id.erudit.org/iderudit/1068535ar

DOI : https://doi.org/10.7202/1068535ar

Aller au sommaire du numéro

Éditeur(s)

HEC Montréal

Université Paris Dauphine

ISSN

1206-1697 (imprimé)

1918-9222 (numérique)

Découvrir la revue

Citer cet article

Dang, R., Houanti, L., Teulon, F. \& Vo, L.-C. (2019). Antecedents of Female Representation on Corporate Boards: An Exploratory Analysis at Board Level from a Socialized Perspective. Management international / International Management / Gestiòn Internacional, 23, 52-63.

https://doi.org/10.7202/1068535ar

\section{Résumé de l'article}

La littérature explique la représentation des femmes dans les conseils d'administration (WOCB) en s'appuyant principalement sur une perspective économique rationnelle. Notre étude est differente dans le sens ou elle se fonde sur une perspective socialisée basée sur le modèle ASA

(attraction-selection-attrition) de Schneider (1987), le cadre de démographie organisationnelle de Pfeffer (1983) et la théorie de l'identité sociale de Tajfel et Turner (1986). Nous avons utilisé un échantillon composé de sociétés françaises répertoriées dans l'indice SBF 120 pour la période 2006-2010 pour analyser l'impact des antécédents suivants du WOCB : les caractéristiques démographiques des administrateurs masculins, le capital humain et le capital social.
Tous droits réservés (c) Management international / International Management / Gestión Internacional, 2019
Ce document est protégé par la loi sur le droit d'auteur. L’utilisation des services d’Érudit (y compris la reproduction) est assujettie à sa politique d'utilisation que vous pouvez consulter en ligne. 


\title{
Antecedents of Female Representation on Corporate Boards: An Exploratory Analysis at Board Level from a Socialized Perspective*
}

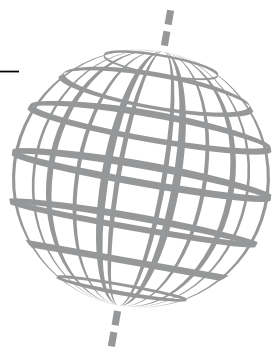

\author{
Antécédents de la représentation féminine dans les conseils \\ d'administration : analyse exploratoire au niveau des conseils \\ d'administration dans une perspective socialisée
}

\section{Antecedentes de la representación femenina en juntas ejecutivas: análisis exploratorio a nivel de juntas desde una perspectiva socializada}

\author{
REY DANG \\ L'HOCINE HOUANTI \\ FRÉDÉRIC TEULON \\ ISTEC Paris \\ La Rochelle Business School \\ IPAG Business School
}

\author{
LINH-CHI VO \\ METIS Lab, École de \\ Management de Normandie
}

\begin{abstract}
The literature explaining the representation of women on corporate boards (WOCB) has mainly relied on a rational economic perspective. Our study differs by relying on a socialized perspec-tive that is based on Schneider's (1987) attraction-selection-attrition (ASA) model, Pfeffer's (1983) organizational demography framework, and Tajfel and Turner's (1986) social identity theory. We used a sample of French companies listed in the SBF 120 index during 2006-2010 to explore the impact of following antecedents of WOCB: male directors' demographic traits, hu-man capital, and social capital.

Keywords: gender; diversity; board of directors; board composition; corporate governance; female directors
\end{abstract}

\section{RÉSUMÊ}

La littérature explique la représentation des femmes dans les conseils d'administration (WOCB) en s'appuyant principalement sur une perspective économique rationnelle. Notre étude est differente dans le sens ou elle se fonde sur une perspective socialisée basée sur le modèle ASA (attraction-selection-attrition) de Schneider (1987), le cadre de démographie organisationnelle de Pfeffer (1983) et la théorie de l'identité sociale de Tajfel et Turner (1986). Nous avons utilisé un échantillon composé de sociétés françaises répertoriées dans l'indice SBF 120 pour la période 2006-2010 pour analyser l'impact des antécédents suivants du WOCB : les caractéristiques démographiques des administrateurs masculins, le capital humain et le capital social.

Mots-Clés : genre; diversité; conseils d'administration; composition du conseil; gouvernance d'entreprise; directrices

\section{RESUMEN}

La literatura explica la representatividad de las mujeres en las juntas ejecutivas (WOCB) sobre todo desde una perspectiva económica racional. Nuestro estudio es distinto porque se basa en una perspectiva socializada, tomando como punto de partida el modelo ASA (atracción-selección-atrición) de Schneider (1987), el marco de demografía organizacional de Pfeffer (1983) y la teoría de la identidad social de Tajfel y Turner (1986). Además, hemos utilizado una muestra compuesta de empresas francesas registradas según el índice SBF 120 para el periodo 20062010 con el objetivo de analizar el impacto/ efecto de los siguientes antecedentes del WOCB: las características demográficas de los hombres administradores/directores/ oficiales, el capital humano y el capital social.

Palabras Clave: género; diversidad; juntas ejecutivas; composición de la junta; gobernanza empresarial; directivas
$\mathrm{B}_{\mathrm{p}}^{\mathrm{o}}$ oard gender diversity has attracted considerable interest in public debate, government agendas and academic research in recent years (Terjesen, Sealy, \& Singh, 2009). The European Commission and countries, such as France, Spain, and Norway, have imposed quotas for female directors on publicly traded companies. Frequent headlines in the popular press call for increased diversity in the workforce (see European Women on Boards). ${ }^{1}$ In academic research, there has been a wide range of descriptive studies examining women directors (e.g. Adams \& Ferreira, 2009;
Hillman, Cannella, \& Harris, 2002; Moulin \& Point, 2012; Singh, Terjesen, \& Vinnicombe, 2008; Westphal \& Stern, 2006).

Although many espouse the advantages of board gender diversity, gender diversity remains low across the globe (Tinsley et al., 2017) and scholars and practitioners have started to question the processes relating to the selection and appointment of board members (e.g. Egon Zehnder, 2016; ${ }^{2}$ Labelle, Francoeur, \& Lakhal, 2015). It has been pointed out that female representation on boards is far from uniform across firms (Hillman,

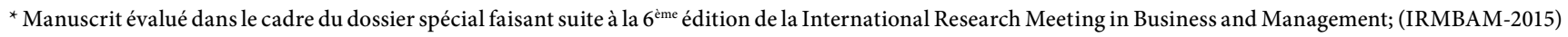
tenu les 2-3 juillet à IPAG Business School Nice - France.

1. European Women on Boards is a European-wide association, which was created for the purpose of promoting board gender diversity.

2. Egon Zenhder (2016). Global Board Diversity Report 2016. DOI: https: //www.egonzehnder.com/files/2016_gbda_digital.pdf. 
Shropshire, \& Cannella, 2007) and countries (Grant Thornton, 2013). ${ }^{3}$ Therefore, there has been a call to address an important question: why do some organizations have women on their boards of directors while others do not (Hillman et al., 2007)? In other words, what are the antecedents of the presence of WOCB?

The literature has provided only partial responses to this question. Studies in this area rely primarily on a rational economic perspective of director selection (Withers, Hillman, \& Cannella, 2012). They typically mobilize agency and resource dependency theories to explain that women directors are appointed because of their ability to carry out monitoring functions (Fama \& Jensen, 1983), bring key resources, or reduce business uncertainties in a firm (Pfeffer \& Salancik, 1978). Studies also consider critical board functions (Hillman \& Dalziel, 2003) to justify their focus on organizational and external changes that provide an impetus for more gender-diverse board composition. Moreover, when relying on a rational economic perspective, scholarly knowledge is limited to research that has taken firm and industry characteristics, such as firm size, diversification strategy, industry type, and network effects (Hillman et al., 2007), as the antecedents of WOCB.

Therefore, this study aims to bring new insights into the antecedents of WOCB by exploring the issue from a socialized perspective (Withers et al., 2012). A socialized perspective argues that the directors appointed are not necessarily those who can optimally serve the best interests of the organization, but those who can serve the preferences and biases of existing board directors or people involved in the selection of directors. More specifically, this research relies on the attraction-selection-attrition (ASA) model (Schneider, 1983, 1987), the organizational demography model (Pfeffer, 1983), and the social identity theory of intergroup behavior (Tajfel \& Turner, 1986). According to these theories, current board directors tend to recruit new members that are characteristically similar to them. These trait preferences are not written recruitment practices, but have become institutionalized over the years (Gregorič, Oxelheim, Randøy, \& Thomsen, 2015). Based on the observation that corporate boards have traditionally been considered as "old boys' clubs" (Singh et al., 2008), we predict that the attributes of male directors, including their demographic traits, human and social capital (Johnson, Schnatterly, \& Hill, 2013), influence the presence of WOCB. As our study is exploratory, we limit our investigation to the attributes of male directors for the sake of space and because these factors have been considered in the literature as being important in influencing the functioning of the organization.

We test our hypotheses with a sample of French companies listed in the SBF 120 index during the period 2006-2010. France is an interesting testing ground for our investigation. According to INSEE, ${ }^{4}$ in 2009 , women accounted for $51.5 \%$ of the French labor force but held only $9.3 \%$ of the $\mathrm{SBF}^{5} 120$ board seats. We examine the following attributes of male directors: average age and age heterogeneity (demographic attributes); functional background heterogeneity, executive ranking heterogeneity, average board tenure and board tenure heterogeneity (human capital); heterogeneity in terms of an elite college/Grande École degree; and heterogeneity in terms of past or current membership of one the elite civil services/grands corps de l'État (social capital). Our analysis reveals that, among these attributes, executive ranking heterogeneity has a significant negative impact on the presence of WOCB. This result suggests that the power dynamic among the current male directors influences the process of recruiting female directors.

Because of the exploratory nature of our study, its findings are modest, but important in two ways. First, our work extends the current literature by preliminary demonstrating that factors influencing the presence of WOCB can be identified not only from a rational economic perspective, but also from a socialized perspective. We respond to the call of Withers et al. (2012) that the social process by which directors are selected remains largely uncharted territory. Second, by relying on a socialized perspective, this study extends the current understanding of the presence of WOCB to another level of analysis. Terjesen et al. (2009) noted that WOCB have been examined primarily through a variety of theoretical frameworks at the meso and macro levels - firm and industry/environment, respectively (e.g. Hillman et al., 2007; Nekhili \& Gatfaoui, 2013). In this study, we show that examining female representation at the board level can reveal interesting findings. In short, although our study finds the correlation between only one attribute of male directors and the presence of WOCB, it contributes to the literature by taking the first step in confirming the role of a socialized perspective, thus the role of board level analysis and the importance of multi-level analysis, in explaining board gender diversity. It provides preliminary empirical evidences for the call to go further in a socialized perspective to examine the presence of WOCB.

\section{Antecedents of Female Representation on Corporate Boards: A Literature Review}

\section{Existing STudies}

We identified five studies that empirically investigated the determinants of WOCB. The most comprehensive study is that of Hillman et al. (2007). They found that WOCB depends on organizational size, industry type, the firm's diversification strategy, and network effects (i.e. linkages to other boards on which female directors are present). Kang, Cheng, and Gray (2007) used agency theory to show that board size and a firm's sector are not antecedents of board gender diversity, while ownership concentration is negatively and significantly related to WOCB. Gregorič, Oxelheim, Randøy, and Thomsen (2009) also found several interesting results: board size, firm size, firm performance (as measured by Tobin's Q), and indebtedness play a significant role in increasing the likelihood of female representation on boards. In contrast, a firm's leverage and

3. Grant Thornton (2013). International Business Report 2013. DOI: http: //www.grantthornton.ie/db/Attachments/IBR2013_WiB_report_final.pdf.

4. INSEE stands for the Institut National de la Statistique et des Études Économiques (the French National Institute for Statistics and Economic Research). The institute collects and publishes information on the French economy and society by carrying out a periodic national census (Tableaux de l'Économie Française Édition, 2011, p. 252).

5. The SBF 120 index is a capitalization-weighted index, which gathers the 120 largest companies by market capitalization and trading volume on Euronext Paris, France's securities market. 
its level of risk are negatively associated with the presence of WOCB. The authors also found that the presence of female directors tends to be more common in the manufacturing and construction industries. A further finding, interestingly, was that the average age of male directors is positively and significantly correlated to the presence of WOCB. A study by Moulin and Point (2012), relying on resource dependency and neo-institutional theories, revealed that firm size and the level of diversification are, respectively, positively and negatively correlated to the presence of WOCB. The major finding of this study is that family shareholding significantly impacts the presence of female directors. Finally, Nekhili and Gatfaoui (2013) showed the correlation between board size, firm size, and family ownership and women's representation on corporate boards.

\section{Current Gaps}

There are two gaps in the existing studies. First, they all rely on a rational economic perspective (Withers et al., 2012), employing the common conceptual frameworks of resource dependency theory and agency theory. According to resource dependency theory, organizations are viewed as open systems that depend on external organizational and environmental contingencies (Pfeffer, 1972; Pfeffer \& Salancik, 1978). The board of directors is perceived as a vehicle for managing external dependency (Pfeffer \& Salancik, 1978), reducing uncertainty (Pfeffer, 1972) and lowering transaction costs associated with environmental interdependency (Williamson, 1984). Directors are recruited when they can provide resources critical for the success of the firm, such as: (a) advice and counsel, (b) legitimacy, and (c) communication, commitment and resources (Hillman et al., 2007). The presence of WOCB depends on what resources they can bring to the organization. According to agency theory, boards of directors ensure that managers serve the interests of shareholders (Fama \& Jensen, 1983). A common assumption of this theory is that shareholders' interests are protected more effectively by independent directors (outsiders) than by inside directors, as they are not beholden to managers. Thus, female directors are more likely to be present only when they are independent directors (Kesner, 1988).

However, factors influencing board gender diversity can also be explained from another perspective that has been acknowledged but has not been used very often: a "socialized perspective" or "social embeddedness perspective", which recognizes the social nature of boards and board processes (Withers et al., 2012). The perspective posits that director nomination and selection processes can be driven by the desire of current directors or nominating committee members to affiliate with those similar to themselves or other social elites and develop a group that is less about good corporate governance and more about social status and prestige. Thus, the search for directors will be biased by social contacts, while selection of the perceived "optimal" director will be influenced by preferences and biases.

Second, as Terjesen et al. (2009) point out, the presence of WOCB can be examined at four levels of analysis: individual, board, firm, and industry/environment. "Individual" refers to the individual director. Theoretical perspectives related to the individual level emphasize the characteristics of directors, principally by using Becker (1964) human capital theory (Hillman et al., 2002; Singh et al., 2008). The "board" level concerns the processes and interactions occurring within boards. At this level, theoretical perspectives focus on group-level processes through social identity approaches (e.g. attraction-selection-attrition or homophily) and social network and cohesion (Huse, 2005). The "firm" level relates to a firm's characteristics. "Industry/environment" concerns national and external environments. By using a rational economic perspective, studies focus on the predictors of WOCB at firm and industry levels. These include organizational characteristics, such as firm size, board size, a firm's sector(s), and some financial indicators (Hillman et al., 2002). It remains unclear, however, how the characteristics of board members influence the presence of female directors. The only exception is a study by Gregorič et al. (2009), which investigated the role of male directors' average age. This is a disappointing gap in the literature, since board members characteristics have been found to play an important role in influencing different organizational issues, such as innovation (Bantel \& Jackson, 1989) and the strategic status quo (Bantel \& Jackson, 1989).

In order to contribute to filling these gaps in the literature, we studied the antecedents of WOCB at the board level from a socialized perspective.

\section{Theoretical Background and Hypotheses}

\section{Director Selection Framework}

Within the socialized perspective, several theories lead to one common argument: incumbent board directors tend to recruit new members with a similar background and characteristics. These theories include social identity theory (Tajfel \& Turner, 1986) and attraction-selection-attrition (ASA) (Schneider, 1987), and the organizational demography model (Pfeffer, 1983).

According to social identity theory (Tajfel and Turner, 1986), individuals use demographic attributes, such as age and gender, to categorize the self and others into social groups. They maintain a positive self-identity by maximizing the differences between in-group members (similar others) and out-group members (dissimilar others). As a result of this self-categorization process, boards are cohesive groups that may display in-group bias by giving favorable treatment to those who are perceived as similar.

The attraction-selection-attrition model (Schneider (1987) assumes that firms evolve toward interpersonal homogeneity. People are drawn to organizations through similarity-attraction. That is, on the supply side, the organization is likely to favor similar candidates and screen out dissimilar candidates. Over time, those who are dissimilar will progressively leave the organization and, across time, the organization's members become homogeneous (e.g. Ployhart, Weekley, \& Baughman, 2006). In corporate boards, board members also tend to become homogeneous over time, as directors with similar characteristics are more likely to be recruited and stay.

Closely related to Schneider's (1987) ASA framework is Pfeffer (1983) model of organizational demography. This model provides a rationale for how and why the demographic compositions of organizations are likely to be related to organizations' outcomes (e.g. Boone, van Olffen, van Witteloostuijn, \& De Brabander, 2004). Theorists in this tradition (Hambrick \& Mason, 1984; Pfeffer, 1983) argue that the diversity of ideas and perspectives 
in decision-making processes reflects the demographic composition of organizational members. Here, "demographic" encompasses age, gender, religion and socioeconomic position, which, among other factors, influence individual behavior. When this theory is applied to the director selection process, it can be expected that board member characteristics influence the composition of the board itself.

\section{Male Directors' Attributes as Antecedents OF WOCB}

The above theories suggest that people in the organization and their characteristics influence the organizational features. In corporate boards, current board members tend to prefer candidates who are similar to them. This creates a "similarity-attraction" (Tsui \& O'Reilly, 1989) paradigm or "attraction" paradigm (Byrne, 1971). We propose that current board directors' similarity-attraction play a key role in board decisions to appoint female directors. As corporate boards are traditionally composed entirely of male directors with very similar profiles (Singh et al., 2008), we hypothesize that the characteristics of male directors are likely to influence board gender diversity. This phenomenon has elsewhere been called "homosocial reproduction" (Kanter, 1977) and "self-cloning” (Burgess \& Tharenou, 2002).

\section{HYPOTHESES}

We argue that the demographic traits, the human and social capital of male directors explain the presence of WOCB. These characteristics of board directors have been commonly considered as having significant influence on a firm (Johnson et al., 2013). We examine two demographic characteristics (average board age and board age heterogeneity), four human capital characteristics (functional background heterogeneity, executive ranking heterogeneity, average board tenure, and board tenure heterogeneity), and two social capital features associated with the French context (Grandes Écoles and grands corps de l'État). We present and develop our hypotheses below.

Age. In line with the organizational demography model, the age of current male directors is a demographic feature that influences board gender diversity. There are reasons for expecting younger board members to be more willing to recruit female directors to the board. First, age is expected to influence a person's attitude. Research has suggested that, due to rigidity and resistance to change, organizational status quo increases with the age of the employees (Hambrick \& Mason, 1984). At the top management level, it has been found that older executives are more resistant to change. For example, they are reluctant to take risky decisions, such as making major changes in the firm's strategic direction (Vroom \& Pahl, 1971); they also tend to avoid any actions that would jeopardize their job, financial security, and career (Carlsson \& Karlsson, 1970). Thus, compared to young male executives, older ones are less likely to accept women in senior positions (Daily, Certo, \& Dalton, 1999). Second, cognitive abilities might diminish with age, such as speed of decision making, confidence in decisions, and reasoning (Hambrick \& Mason, 1984). Older managers are less likely to adapt to external changes, such as emerging norms and the pressure to include women on the corporate board. Therefore, we predict that recruiting female directors is expected to encounter resistance from older male board members.
Hypothesis 1a: The average age of male board members is negatively related to the presence of WOCB.

Age heterogeneity. According to the ASA model and social identity theory, age heterogeneity among male board members is expected to influence positively the recruitment of women to the board. One reason is that people of the same age cohort experience similar social, political, and economic events at a similar time in their lives, which has a fundamental role in shaping attitudes and values (Bantel \& Jackson, 1989). Wagner, Pfeffer, and O'Reilly III (1984) argued that there is likely to be more similarity among people of the same age than among those of different ages. Similarity in age is a salient basis for group categorization, which hinders the inclusion of new members that are different from the existing ones (Stangor, Lynch, Duan, \& Glas, 1992). Another reason is that people of various ages have faced different work-related and non-work-related experiences and have accepted social values at different stages in their lives. As people of different age cohorts tend to differ in attitudes, values, and beliefs, groups whose members are heterogeneous in terms of age are likely to be less cohesive (Wagner et al., 1984), and the problem of in-group categorization is less prominent (Ali et al., 2013). Therefore, we put forward a hypothesis that a board of male directors, who are heterogeneous in terms of age, is more likely to recruit female directors due to the lack of cohesion among the members and their diverse perspectives.

Hypothesis 1b: The age heterogeneity of male board members is positively related to the presence of WOCB.

Functional background heterogeneity. The ASA model and social identity theory support the argument that diversity in the functional background of male board members has an impact on the presence of WOCB. Functional background represents executives' professional orientations, including their implicit causal models, vocabularies, and internal and external networks (Hambrick, Cho, \& Chen, 1996). Thus, work experiences in functional areas shape cognitive and attitudinal perspectives (Bantel \& Jackson, 1989). Managers with different functional experience backgrounds are likely to differ in their attitudes, knowledge, and perspectives (Hambrick \& Mason, 1984). Such diversity is expected to motivate the recruitment of WOCB. Thus, we hypothesize that the presence of WOCB is favored by a more diverse composition of male board members in terms of functional background.

Hypothesis 2: The heterogeneity of male board members' functional backgrounds is positively associated with the presence of WOCB.

Executive ranking heterogeneity. Executive ranking heterogeneity is the degree of diversity in the hierarchical levels of board members' positions. It indicates the relative power relationship between board members. Based on the organizational demography model, it can be argued that this power dynamic has an impact on the interaction processes within the top executive group, and hence on the outcomes of its decision making (Smith, Smith, \& Verner, 2006). When the executive ranking is heterogeneous, power is highly dispersed (Pitcher \& Smith, 2001). This situation impedes the inclusion of WOCB, as heterogeneity in executives' power leads to decision-making processes that are in the hands of the most powerful executives (Smith et al., 2006). Female candidates for the board would then be chosen 
based on the preference of the most powerful board members. Thus, it is expected that the presence of WOCB is negatively related to the executive ranking heterogeneity of male directors.

Hypothesis 3: The executive ranking heterogeneity of male board members is negatively associated with the presence of WOCB.

Average board tenure. In accordance with the ASA model and social identity theory, the average organizational tenure of team members is more likely to affect their attitude toward the inclusion of new members. Indeed, Katz (1982) found that groups that have been together for a long time tend to share the same cognitive bases, which is reflected in standardized ways of communication and homogeneity of perspective. Long tenure among a group of top executives leads to higher commitment to the status quo (Staw \& Ross, 1980) and pre-existing organizational values (Schmidt \& Posner, 1983). The longer the members work together, the higher the social pressures within the board for conformity. They also become less receptive to changes that may threaten their patterns of behavior (Staw, 1977). Thus, we predict that long-standing board members are more inclined to maintain their places as well as the "social cohesion" (Michel \& Hambrick, 1992) within the board by excluding female directors. It is expected, therefore, that longevity of board tenure is negatively related to the recruitment of women in boardrooms.

Hypothesis 4a: The average longevity of board tenure of male board members is negatively related to the presence of WOCB.

Board tenure heterogeneity. In light of the ASA model and social identity theory, a board's heterogeneity in board tenure should lead to diverse opinion and stimulate consideration of new female board members. Experiences inside an organization produce a common vocabulary and a similar interpretation of events (Wiersema \& Bantel, 1992). Tenure heterogeneity within a group of top executives indicates that the members have been appointed at different times, suggesting that new and different perspectives regarding the strategic vision, as well as new and different forms of knowledge and skill, have been added to the group. The phenomenon of in-group and out-group categorization is, therefore, less noticeable (Ali et al., 2014). It has been demonstrated that group tenure homogeneity helps reduce the phenomenon of groupthink (Janis, 1972). This helps promote a greater diversity of perspectives (Wiersema \& Bantel, 1992). Thus, we hypothesize that board tenure heterogeneity of male directors promotes gender diversity on boards.

Hypothesis 4b: The heterogeneity of board tenure longevity of male directors is positively related to the presence of WOCB.

Social capital. In this study, we refer to "social capital" as the resources that an individual gains through social network or elite institution ties (e.g. club membership) which are critical to an organization and that person's professional advancement (e.g. Useem \& Karabel, 1986). Relying on the ASA model, social identity theory and the organizational demography model, it can be argued that directors' social capital is likely to affect both their behavior and the functioning of the boards to which they belong (Johnson et al., 2013). Here, we hypothesize that heterogeneity in the social status of male directors is likely to influence the appointment of female directors. Indeed, directors with prestige and status are likely to seek to maintain and enhance their social standing (Johnson, Schnatterly, Bolton, \& Tuggle, 2011).

In France, two key features characterize directors' social capital: ties to other organizations and the social standing they acquire though an elite college education (from a Grande École) and past or current membership of a civil service (one of the grands corps de l'État) (see Bourdieu, 1996; Maclean, Harvey, \& Chia, 2010; Nguyen, 2012). There is true "friendship" among graduates from the same Grande École and the same grand corps de l'État (Kadushin, 1995). For example, a number of years spent in the French Treasury (one of the branches of the civil service) has a significant impact on being part of an "inner circle". As friends, these individuals are more likely to sit on the same board of directors (Kadushin, 1995). Moreover, the French elites form a socially homogeneous group in which cooperation is the norm and competition is low (Frank \& Yasumoto, 1998). Very few women are present in those spheres of power, as their participation in elite colleges and the civil service was not allowed until the 1970s. The admission of women to the École Polytechnique, which is the most prestigious school in France, started in 1972. Consequently, women have a stronger chance of joining boards only if the board of directors is heterogenous in terms of social capital. The following hypotheses were developed.

Hypothesis 5a: The heterogeneity of male directors with respect to degrees from an elite college (Grande École) is positively associated with the presence of WOCB.

Hypothesis 5b: The heterogeneity of male directors with respect to former membership of an elite civil service (grands corps de l'État) is positively associated with the presence of WOCB.

\section{Research Design}

\section{SAMPLE AND DATA}

The sample for this study consists of all the companies listed in the SBF 120 index during the 2006-2010 period. We identified the composition of the boards of directors of these companies. The final dataset consisted of 115 firms, 564 firm-year observations and 6,732 directors. ${ }^{6}$

We used different sources of information to identify the board composition of the sample companies: annual reports, Factiva, Diane, and the Internet. In the biography section of the annual reports, there is information regarding directors' names, age (or birth date), education, function and position, and year of appointment. All the information collected from the reports was crosschecked or completed using the Factiva (Dow Jones \& Company) and Diane (Bureau van Dijk) databases. Financial data were taken from the Thomson ONE Banker database.

\section{VARIABLES}

Dependent variable. Consistent with Liu, Wei, and Xie (2014) and Nekhili and Gatfaoui (2013), we measured the presence of WOCB by the actual number of WOCB.

Following Hillman et al. (2007) and Ahern and Dittmar (2012), we identified the directors' gender using four sources of information: annual report, which provides this information in 
the biography section; first name of the director (e.g. Jacques = male and Sophie = female); photograph of the directors whose names did not clearly indicate their gender.

Independent variables. A director's age and his/her board tenure were measured in years (Bilimoria \& Piderit, 1994). We then aggregated the values and calculated the mean.

For functional background, we were inspired by the framework of Hambrick and Mason (1984) and the categories used by Hambrick et al. (1996). Specifically, functional background is categorized into five groups in our study: top managers (i.e. CEO [chief executive officer], chair of the board, COO [chief operating officer], CFO [chief financial officer], CIO [chief information officer], and managing director ["directeur general" in French]); output function (i.e. R\&D [research and development], sales, marketing, and international); throughput function (i.e. IT [information technology], HRM [human resource management], secretariat, production, process engineering, and accounting); peripheral function (i.e. public affairs, law, and finance); and other (e.g. politician, professor, and board director). These groups were coded from 1 to 5 , where $1=$ top managers and $5=$ other.

We coded the executive ranking of directors by relying on the coding scheme developed by Helfat, Harris, and Wolfson (2006): CEO, chair of the board, managing director, functional manager, state representative, employee, and miscellaneous (e.g. professor, retiree, and politician). These levels were coded from 1 to 7 , where $1=\mathrm{CEO}$ and $7=$ miscellaneous

Following Nguyen (2012), we limited the French Grandes Écoles to the best engineering schools (École Polytechnique; École des Mines; École des Ponts Paris Tech; École Centrale Paris; École supérieure d'électricité - Supélec; and École national supérieure de l'aéronautique et de l'espace - SUPAERO) and business schools (HEC; ESSEC; and ESCP Europe), and three elite institutions (Ecole Nationale d'Administration - ENA; École normale supérieure, rue d'Ulm, Paris; and Sciences Po, Paris). This variable was coded using a dichotomous scheme, with 1 indicating that a board member had graduated from one of these Grandes Écoles, and 0 otherwise.

The grands corps de l'État exclusively include: (a) the Conseil d'État (the Council of State); (b) the Cour des comptes (Court of Auditors); (c) the Inspection générale des finances (General Inspection of Finances); (d) the Corps des Mines (State Engineers of the Mines); (e) the Ingénieur des ponts, des eaux et des forêts (State Engineers of Bridges, Waters, and Forests); (f) the administrateurs of l'Insee (French National Institute for Statistics and Economic Studies); and (g) the corps des ingénieurs de l'armement (Military Ordnance Engineers). This variable was also coded using a dichotomous scheme, with 1 indicating that the given board member has past or current membership in one of these grands corps de l'Etat, and 0 otherwise.

The heterogeneity of directors in terms of age, functional background, executive ranking, and board tenure was measured using Blau's $(1977)^{7}$ index of heterogeneity: $\left(1-\sum p_{i}^{2}\right)$, where $p_{i}$ is the proportion of directors in each of the $i$ number of categories. For interval data, as suggested by Allison (1978), we used the coefficient of variation, defined as the standard deviation divided by the mean. This provides a direct method for obtaining a scale invariant measure of dispersion, since it is more sensitive to relative difference than to absolute difference.

Finally, with regard to the Grandes Écoles and the grands corps de l'État, the heterogeneity was measured by dividing the number of directors graduating from elite colleges or having a prestigious civil service background by the total number of board directors. We used this measure rather than the Blau index, since this variable is more meaningful for capturing the diversity on corporate boards. It should be noted, however, that the two measures provide the same results. ${ }^{8}$

Control variables. We included board size as a control variable. As large groups are more likely to be heterogeneous (Bantel \& Jackson, 1989), board size has an impact on the inclusion of WOCB. We defined board size as the natural logarithm of the number of directors on corporate boards (Yermack, 1996). Another control variable is firm size (which is defined as the natural log of total firm assets). Increases in firm size add complexity in terms of structural elaboration and formalized systems for planning and control, as well as resource allocation (Quinn \& Cameron, 1983). Therefore, increases in firm size can create progressively stronger resistance to change (Tushman \& Romanelli, 1985). Large firm size should thus be associated with a low likelihood of major changes on corporate boards. Our third control variable is firm performance. Firm performance (measured by the return on assets [ROA]) might influence board gender diversity (Hillman et al., 2007). For example, poor performance is often the impetus for changes in strategy (Tushman \& Romanelli, 1985), thus possibly resulting in greater gender diversity on boards. Finally, we added both industry (using a two-digit SIC code) and year dummy variables.

\section{Model AND Estimation Model}

Our model is as follows:

(Number of female directors) $)_{i, t}=$ $\alpha+\beta_{1}(\text { Age })_{i, t}+\beta_{2}$ (Age heterogeneity) ${ }_{i, t}$

$+\beta_{3}$ (Functional background heterogeneity) ${ }_{i, t}$

$+\beta_{4}$ (Executive ranking heterogeneity) ${ }_{i, t}$

$+\beta_{5}{\text { (Board tenure })_{i, t}}$

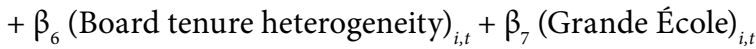

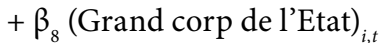

$+\beta_{9}(\text { Firm size })_{i, t}+\beta_{10}(\mathrm{ROA})_{i, t}$

$+\beta_{11}$ (Board size $)_{i, t}+\mu_{i}+\eta_{t}+\varepsilon_{i, t}$

where $i$ denotes firms in the sample $(i=1,2, \ldots, 115)$ and $t$ refers to time period $(t=2006,2007, \ldots, 2010)$. The definitions of the variables used in Eq. [1] are given in the 'Variables' Subsection above; $\mu_{i}$ represents unobserved firm fixed effects; $\eta_{t}$ represents time-specific effects that are time-variant and common to all companies (e.g. the macro-economic conditions); and $\varepsilon_{i, t}$ is the classical error term, which is assumed to be independent and identically distributed. The primary estimation method for Eq. [1] is the Poisson fixed-effects model. We used the fixed-effects approach to mitigate omitted variables and address unobserved

7. A Blau's index can range from 0 , when there is only one gender on corporate board, to 0.50 , when the numbers of male and female directors on boards are equal.

8. The results are available from the authors on request. 
changes over time (Wooldridge, 2010). The evaluation of the parameters of this model is based on the conditional maximum likelihood of Andersen (1970). The idea is obtain an estimator $\beta^{\mathrm{FE}}$ without having to estimate each of $\theta_{i}^{\mathrm{FE}}$ (the heterogeneity parameter). This yields to the following estimated parameters:

$$
\sum_{i=1}^{n} \sum_{t=1}^{T} x_{i, t}\left(\eta_{i, t}-\lambda_{i, t}^{F E} \frac{\sum_{t} \eta_{i, t}}{\sum_{t} \lambda_{i, t}^{F E}}\right)=0
$$

with $x_{i, t}$ a set of predictor variables that vary over time; $i$ denotes firms in the sample $(i=1,2, \ldots, 115)$ and $t$ refers to time period $(t=2006,2007, \ldots, 2010) . N_{i, t}$ is supposed to follow a Poisson distribution with $\theta_{\mathrm{i}} \lambda_{i, t} i=1,2, \ldots, \mathrm{N}(=115), t=$ $2006,2007, \ldots, 2010 . \theta_{i} \lambda_{i, t}$ is the product of a static factor $\theta_{i}$ and a dynamic factor $\lambda_{i, t}$. The former accounts for the dependence between observations relating to the same insured. The latter introduces the observable characteristics (that are allowed to vary in time). Generally, $\ln \lambda_{i, t}$ is expressed as a linear combination of the observable characteristics, that is $\lambda_{i, t}=\exp \left(\beta_{0}+\beta^{\prime} x_{i, t}\right)$, where $\beta_{0}$ is the intercept, $\beta^{\prime}=\left(\beta_{1}+\ldots+\beta_{\mathrm{p}}\right)$ is a vector of regression parameters for explanatory variables $x_{i, t}=\left(x_{i, t, 1}+\ldots+x_{i, t, p}\right)^{\prime}$.

Note that only insureds with varying characteristics (and at least one claim) are used in the estimation of $\beta^{\mathrm{FE}}$. Estimates of $\theta_{i}^{\mathrm{FE}}$ can be obtained from:

$$
\theta_{i}^{F E}=\frac{\sum_{t} \eta_{i, t}}{\sum_{t} \lambda_{i, t}^{F E}}
$$

$\beta^{\mathrm{FE}}$ and $\theta_{\mathrm{i}}^{\mathrm{FE}}$ are consistent when $\mathrm{T} \rightarrow \infty$ and $\mathrm{N} \rightarrow \infty$, but only the estimate of $\beta^{\mathrm{FE}}$ is consistent with fixed $\mathrm{T}$ and $\mathrm{N} \rightarrow \infty$. ${ }^{9}$

\section{Findings}

\section{Descriptive Statistics and Correlation Analysis}

Table 1 presents the summary statistics of our sample. We found that the average number of female directors of SBF 120 companies was slightly above 1 during 2006-2010 (1.067). This result shows a higher level of WOCB compared to the work of Nekhili and Gatfaoui (2013). Panel F of Table 1 shows the distribution of female directors during the sample period. The average number of female directors in the sample boardrooms increased over time. The difference in the means between 2006 and 2010 was statistically significant. This improvement among French listed companies over time has been confirmed elsewhere (Dang, Bender, \& Scotto, 2014).

Table 2 provides the correlation matrix of our key variables, as well as the corresponding variance inflation factors (VIF). Regarding multicollinearity, as a rule of thumb, a correlation of 0.7 or higher for absolute values may indicate a multicollinearity issue. Table 2 shows that the highest correlation coefficient (in bold) exists between functional background heterogeneity and executive ranking heterogeneity (0.669). The VIF values were also generated to ascertain possible multicollinearity issues. No values exceed 3 , which is significantly below the accepted value of 10 (Chatterjee \& Hadi, 2012).

\section{Results}

Table 3 provides the results of our analysis. In order to test our hypotheses, we considered significance levels of $1 \%$ and $5 \%$.

\begin{tabular}{|c|c|c|c|c|c|}
\hline & mmary & $\begin{array}{l}1 \\
\operatorname{ics}(\mathrm{N}=\end{array}$ & & & \\
\hline Variables & Mean & Median & STD & Minimum & Maximum \\
\hline \multicolumn{6}{|c|}{ Panel A: Female directors } \\
\hline Number of female directors & 1.067 & 1.000 & 1.105 & 0.000 & 7.000 \\
\hline \multicolumn{6}{|c|}{ Panel B: Demographic variables } \\
\hline Age & 58.990 & 59.515 & 4.748 & 41.300 & 72.818 \\
\hline Age heterogeneity & 0.146 & 0.140 & 0.052 & 0.036 & 0.350 \\
\hline \multicolumn{6}{|c|}{ Panel C: Human capital variables } \\
\hline Functional background heterogeneity & 0.370 & 0.408 & 0.143 & 0.000 & 0.651 \\
\hline Executive ranking heterogeneity & 0.698 & 0.722 & 0.097 & 0.245 & 0.833 \\
\hline Board tenure & 5.760 & 5.215 & 3.240 & 0.117 & 19.167 \\
\hline Board tenure heterogeneity & 0.664 & 0.630 & 0.335 & 0.000 & 3.000 \\
\hline \multicolumn{6}{|c|}{ Panel D: Social capital variables } \\
\hline Grande École & 0.464 & 0.485 & 0.218 & 0.000 & 1.000 \\
\hline Grands corps de l'État & 0.144 & 0.100 & 0.387 & 0.000 & 8.758 \\
\hline \multicolumn{6}{|c|}{ Panel E: Control variables } \\
\hline Board size & 11.936 & 11.000 & 3.775 & 3.000 & 23.000 \\
\hline Firm size & 9.068 & 8.893 & 1.866 & 4.515 & 14.543 \\
\hline Return on assets (\%) & 4.945 & 4.786 & 7.770 & -47.204 & 49.251 \\
\hline
\end{tabular}
We tested two different regression models: (1) the control

9. One of the reviewers suggested to linearize the variables (dependent and independents). We followed this comment but obtained the same results. Thus, we do not report the results due to the lack of space. They are available upon request. 
variables, and (2) the full model. In model 1, regressing the number of female directors on the control variables reveals that the correlation with firm size and board size is positive and significant at the 5\% and 1\% levels, respectively. Model 2 includes the control variables and all the independent variables. It provides the results of our hypotheses, as presented below.

Hypothesis la predicts that the average age of male directors is negatively associated with the number of female directors. The evidence in model 2 provides no support for this hypothesis, as the coefficient is not significant $(z=0.44)$. The positive association is opposite to the predicted negative association. Hypothesis la is rejected. Hypothesis $1 \mathrm{~b}$ predicts that the age heterogeneity of male directors is positively associated with the number of female directors. The evidence in model 2 provides no support for this hypothesis. The coefficient is not significant at the $10 \%$ level $(z=-1.00)$. Hypothesis $1 \mathrm{~b}$ is also rejected. Although Gregorič et al. (2009) found that the age of male directors is significantly correlated to the presence of WOCB, our results show that this variable is not necessarily an antecedent of the appointment of female directors.

Hypothesis 2 predicts that functional background heterogeneity is positively associated with the number of female directors. The coefficient for functional background heterogeneity is not significant at the $10 \%$ level $(z=-1.55)$. Hypothesis 2 is not supported. This implies that diverse perspectives generated by functional background heterogeneity make it difficult for boards to reach a common decision on controversial issues such as WOCB.

Hypothesis 3 predicts that executive ranking heterogeneity is negatively associated with the number of female directors. The evidence in Table 3 (model 2) supports this hypothesis, as the coefficient for executive ranking heterogeneity is negative and significant at the $5 \%$ level $(\mathrm{z}=-2.00)$. Hypothesis 3 is supported. This result suggests that when a board is heterogeneous in terms of power and authority, women are less likely to be appointed.

Hypothesis 4a predicts that the average board tenure of male directors is negatively associated with the number of female directors. The evidence in model 2 shows that the two variables are positively correlated. Hypothesis $4 \mathrm{a}$ is not supported. It should be noted that this result is the opposite of our hypothesis and can be explained by the argument that the sample boardrooms have not had enough time to cultivate group dynamics in order to leverage fully the demographic traits of their members. Indeed, Bantel and Jackson (1989) defined a 'short' tenure as the difference between the mean of board tenure and one standard deviation. Using this calculation, we obtained 2.51 years, while those authors found an average tenure of 5.76 years.

Hypothesis $4 \mathrm{~b}$ predicts that the board tenure heterogeneity of male directors is positively associated with the number of female

\begin{tabular}{|c|c|c|c|c|c|c|}
\hline \multicolumn{7}{|c|}{$\begin{array}{c}\text { TABLE } 2 \\
\text { Matrix of correlation }\end{array}$} \\
\hline & & 1 & 2 & 3 & 4 & 5 \\
\hline 1 & Number of female directors & 1.000 & & & & \\
\hline 2 & Age & $0.202^{* * *}$ & 1.000 & & & \\
\hline 3 & Age heterogeneity & -0.058 & $-0.319 * * *$ & 1.000 & & \\
\hline 4 & Functional background heterogeneity & -0.035 & $0.287^{* * *}$ & $0.100 * *$ & 1.000 & \\
\hline 5 & Executive ranking heterogeneity & 0.015 & $0.234^{* * *}$ & $0.275^{* * *}$ & $0.669 * * *$ & 1.000 \\
\hline 6 & Board tenure & $0.205^{* * *}$ & $0.264^{* * *}$ & $-0.190 * * *$ & -0.061 & $-0.126 * * *$ \\
\hline 7 & Board tenure heterogeneity & $0.132 * * *$ & 0.024 & $0.083^{* *}$ & 0.049 & $0.149 * * *$ \\
\hline 8 & Grande École & 0.005 & 0.048 & 0.037 & 0.018 & $0.229 * * *$ \\
\hline 9 & Grands corps de l'État & 0.042 & 0.048 & -0.034 & 0.028 & 0.058 \\
\hline 10 & Board size & $0.423^{* * *}$ & $0.187 * * *$ & $0.083^{* *}$ & $0.265^{* * *}$ & $0.448^{* * *}$ \\
\hline 11 & Firm size & $0.367^{* * *}$ & $0.321^{* * *}$ & $-0.144^{* * *}$ & $0.127 * * *$ & $0.256^{* * *}$ \\
\hline \multirow[t]{2}{*}{12} & Return on assets & 0.055 & $-0.165^{* * *}$ & $0.103^{* *}$ & -0.019 & 0.020 \\
\hline & VIF & 1.40 & 1.53 & 1.35 & 1.98 & 2.57 \\
\hline & & 6 & 7 & 8 & 9 & 10 \\
\hline 6 & Board tenure & 1.000 & & & & \\
\hline 7 & Board tenure heterogeneity & $0.157^{* * *}$ & 1.000 & & & \\
\hline 8 & Grande École & $-0.165^{* * *}$ & -0.047 & 1.000 & & \\
\hline 9 & Grands corps de l'État & -0.072 & 0.018 & $0.090 * *$ & 1.000 & \\
\hline 10 & Board size & -0.073 & $0.165^{* * *}$ & $0.096 * *$ & $0.122 * * *$ & 1.000 \\
\hline 11 & Firm size & -0.059 & 0.047 & $0.228 * * *$ & $0.129 * * *$ & $0.644^{* * *}$ \\
\hline \multirow[t]{2}{*}{12} & Return on assets & 0.031 & 0.054 & $0.088^{* *}$ & -0.028 & 0.027 \\
\hline & VIF & 1.22 & 1.09 & 1.21 & 1.03 & 2.16 \\
\hline & & 11 & 12 & & & \\
\hline 11 & Firm size & 1.000 & & & & \\
\hline \multirow[t]{2}{*}{12} & Return on assets & $-0.104^{* *}$ & 1.000 & & & \\
\hline & VIF & 2.09 & 1.08 & & & \\
\hline
\end{tabular}

Asterisks indicate significance at the $0.01\left(^{(* *)}\right.$ and $0.05(* *)$ levels. VIF = variance inflation factors. 
directors. We find that the relationship is not significant at the $10 \%$ level $(z=1.57)$. Hypothesis $4 \mathrm{~b}$ is not supported. This insignificant relationship implies that the variability in tenure of male directors does not facilitate the recruitment of female directors.

Hypothesis 5a predicts that heterogeneity among male directors with respect to degrees from an elite institution (Grande École) is positively associated with the number of female directors. The coefficient for elite institutions is not significant at the $10 \%$ level $(z=1.53)$. Hypothesis $5 \mathrm{a}$ is rejected. Hypothesis $5 \mathrm{~b}$ predicts that heterogeneity among male directors with respect to past or current membership of the elite civil services (grands corps) is positively associated with the number of female directors. The coefficient for the grands corps is not significant at the $10 \%$ level $(z=1.40)$. Hypothesis $5 \mathrm{~b}$ is rejected. The lack of significance of these variables can be explained by several reasons. Unlike previous studies (e.g. Maclean et al., 2010; Nguyen, 2012), we observed that only $47 \%$ of French directors from our sample came from elite institutions (Grandes Écoles) and $14 \%$ had served as civil servants (grands corps de l'État). This implies that less than half of these directors come from this "elite circle". This does not constitute a priori a "small world", as suggested by Nguyen (2012). This finding can be explained by our sample being more recent than samples in other studies of French boards in the literature, in which data were collected in the late 1990s and early 2000s (e.g. Nguyen, 2012). Thus, there is a major new trend in the French business world: the social capital of French directors is becoming less important in influencing board gender diversity.

Among the control variables, firm size $(z=2.27)$ and board size $(z=4.39)$ were significantly associated with the number of female directors. Hillman et al. (2007) and Moulin and Point (2012) also had similar findings. The non-significant relationship between firm performance and WOCB may not be a surprising result, as Hillman et al. (2007) and Moulin and Point (2012), among others, had the same finding.

\section{Concluding Remarks}

\section{Discussion}

This article addresses the process of female board director selection and appointment. The question is puzzling as to why some organizations have WOCB while others do not, despite the acknowledged advantages of board gender diversity and pressure from institutional settings. This phenomenon has only been partially answered, as existing studies rely primarily on a rational economic perspective of director selection, thereby overlooking a socialized perspective of director selection and limiting the analysis to firm and industrial levels.

In this study, we examined the antecedents of female representation on corporate boards by adopting a socialized (or social embeddedness) perspective, as suggested by Withers et al. (2012). More precisely, our theoretical background stemmed from Schneider (1987) ASA model, Pfeffer (1983) organizational demography perspective, and Tajfel and Turner (1986) theory of social identity. We tested our hypotheses using a sample of French companies listed in the SBF 120 index from 2006 to 2010. We used a fixed-effects Poisson regression model for panel data.

\begin{tabular}{|c|c|c|c|}
\hline \multicolumn{4}{|c|}{$\begin{array}{c}\text { TABLE } 3 \\
\text { Results of the FE Poisson model }\end{array}$} \\
\hline Variables & $\begin{array}{l}\text { Predicted } \\
\text { direction }\end{array}$ & $\begin{array}{c}\text { Model 1: } \\
\text { Control variables }\end{array}$ & $\begin{array}{l}\text { Model 2: } \\
\text { Full model }\end{array}$ \\
\hline \multicolumn{4}{|l|}{ Control variables } \\
\hline Firm size & & $\begin{array}{l}0.709 * * \\
{[3.016]}\end{array}$ & $\begin{array}{c}0.448^{* *} \\
{[2.274]}\end{array}$ \\
\hline Return on assets & & $\begin{array}{c}0.006 \\
{[0.672]}\end{array}$ & $\begin{array}{c}0.008 \\
{[0.881]} \\
\end{array}$ \\
\hline Board size & & $\begin{array}{c}0.128^{* * *} \\
{[3.248]}\end{array}$ & $\begin{array}{c}0.174^{* * *} \\
{[4.387]}\end{array}$ \\
\hline \multicolumn{4}{|l|}{ Demographics } \\
\hline Age & - & & $\begin{array}{c}0.014 \\
{[0.443]}\end{array}$ \\
\hline Age heterogeneity & + & & $\begin{array}{c}-2.147 \\
{[-0.998]}\end{array}$ \\
\hline \multicolumn{4}{|l|}{ Human capital } \\
\hline $\begin{array}{l}\text { Functional back- } \\
\text { ground heterogeneity }\end{array}$ & + & & $\begin{array}{c}-0.755 \\
{[-1.555]}\end{array}$ \\
\hline $\begin{array}{l}\text { Executive ranking } \\
\text { heterogeneity }\end{array}$ & - & & $\begin{array}{c}-1.574 * * \\
{[-1.995]}\end{array}$ \\
\hline Board tenure & - & & $\begin{array}{c}0.098 * * * \\
{[2.838]}\end{array}$ \\
\hline $\begin{array}{l}\text { Board tenure } \\
\text { heterogeneity }\end{array}$ & + & & $\begin{array}{c}0.214 \\
{[1.567]}\end{array}$ \\
\hline \multicolumn{4}{|l|}{ Social capital } \\
\hline Grande École & + & & $\begin{array}{c}0.609 \\
{[1.533]}\end{array}$ \\
\hline Grands corps & + & & $\begin{array}{c}0.049 \\
{[1.403]}\end{array}$ \\
\hline Industry dummies & & Yes & Yes \\
\hline Firm fixed-effects & & Yes & Yes \\
\hline Year dummies & & Yes & Yes \\
\hline $\begin{array}{l}\text { Number of } \\
\text { observations }\end{array}$ & & 564 & 564 \\
\hline Wald $\chi^{2}$ & & $32.21 * * *$ & $70.66^{* * *}$ \\
\hline Prob $>\chi^{2}$ & & $0.000 * * *$ & $0.000 * * *$ \\
\hline Pseudo R2 & & 0.291 & 0.357 \\
\hline
\end{tabular}

This table reports empirical results from Equ. [1]. z-statistics are given in brackets and based on robust standard errors (Wooldridge, 1999). All specifications include industrydummies (unreported). Asterisks indicate significance at the $0.01(* * *)$ and $0.05(* *)$ levels.

Three categories of male directors' attributes were considered: demographic characteristics, human capital, and social capital. These attributes have been shown elsewhere to have an increasingly important impact on a firm's outcomes (Johnson et al., 2013). However, our investigation showed that not all of these attributes are antecedents of the presence of WOCB. Concerning the demographic attributes, we found that the average age of male directors and their age heterogeneity do not influence female representation on corporate boards. In terms of human capital, the variable associated with executive ranking heterogeneity is negatively and significantly correlated to the likelihood of female representation on corporate boards. Functional background heterogeneity, by contrast, is not significantly correlated to board gender diversity. Similarly, the average length and heterogeneity of board tenure do not promote gender diversity in the boardroom. Regarding 
social capital, neither of the associated variables is significant at the $10 \%$ level. With regard to the control variables, we found that firm size and board size positively and significantly impact the presence of WOCB, while there was no correlation found for firm performance.

In summary, our results have several implications. First, we have shown which characteristics of male directors are and are not antecedents of WOCB. This has implications for scholars and practitioners with regard to the issue of when and why women are appointed to the board of one firm but not another. Specifically, executive ranking heterogeneity does not promote board gender diversity. The power dynamic within the board is expected to play an important role in influencing board gender diversity. Our results disconfirm one antecedent of WOCB that has always been considered as vital in the French culture: male board members holding degrees from elite colleges and past/current membership of civil services. Nguyen $(2011,2012)$ showed that graduating from a French Grande École and membership of one of the nation's grands corps de l'État were prerequisites for becoming directors using late-1990s and early-2000s data. Being part of the French elites would have made it easier for women to join the board. But this is no longer true in our 2006-2010 data. Members of French boards now come from a wide range of educational backgrounds. Board members' degrees from elite schools and past/current membership of the civil service have come to have less influence on the presence of WOCB over time. It can be stated that there has been a change in the extent to which elite education can influence women's careers in France. The image of French boards as a closed circle of old friends is changing. These findings represent areas of opportunity, both for women seeking to enter the boardroom and firms wishing to improve their board gender diversity.

Second, our statistics indicate that heterogeneity may be positive or negative in terms of its relationship with the presence of female directors on a board, although the relationship was not statistically significant. Some diversity is beneficial (in our case, board tenure, Grande École, and grands corps). However, beyond a certain point, diversity may be harmful (e.g. in age, functional background, or executive ranking). This confirms the conclusion of Golden and Zajac (2001) that the effect of heterogeneity may not be linear. Board heterogeneity can be a double-edged sword.

\section{Contributions}

Our study is exploratory because it is one of the firsts in investigating board gender diversity from a socialized perspective. Due to its exploratory nature, the findings are important despite a high number of hypotheses being rejected. First, the results of our study show that a socialized perspective does indeed offer an additional lens for the investigation of the process of female director selection and appointment. Compared to a rational economic perspective, which emphasizes the rationality of managerial decisions, a socialized perspective consider the complex, social and biased nature of decisions. Our findings empirically support the argument of a socialized perspective that the selected directors do not necessarily serve the best interests of the overall organization, but reflect the preferences and biases of those who are already on the board. The value of adjusted $\mathrm{R}^{2}$ (McFadden $\mathrm{R}^{2}$ ) in our full model is of $35.7 \%$ (cf. Table 3). It is not significantly high but does provide preliminary evidences reinforcing the conceptual foundation for the investigation of the influence of male directors' characteristics on female director selection. In this way, it brings into attention male directors' attributes in studying WOCB.

Second, we show that by relying on a socialized perspective, the analysis of board gender diversity can be extended to the board level. Our work preliminarily proves that by relying on a socialized perspective, we can the reveal some new antecedents of female representation on boards, which are related to male directors' characteristics. This provides an understanding that is complementary to the firm-and industry-level studies of the antecedents of the presence of WOCB that are found in the literature. These antecedents include firm performance, firm size, industry type, firm ownership, and firm strategy.

Moreover, by providing empirical support for the extension of WOCB analysis to the board level, our work supports the argument that the representation of WOCB needs to be examined through a multidimensional lens. On the one hand, there are four levels of analysis for WOCB: individual, board, firm, and industry and environment (Terjesen et al., 2009). While our research focuses on the board level, the regression models suggest that the relationships are more complex: both firm size and board size have a positive and significant impact on female representation on boards. On the other hand, the value of adjusted $\mathrm{R}^{2}\left(\mathrm{McFadden} \mathrm{R}^{2}\right)$ in our full model implies that other variables reflecting the attributes of male directors, such as their skills, experience, and educational background, need to be considered. These results provide further support for the conclusion of Withers et al. (2012) that the presence of WOCB needs to be examined through an integrated framework.

\section{Limitations AND AVEnUes for Future Research}

Our study suffers from some limitations. As our study is only exploratory, additional studies should be carried out to confirm and extend our results. Besides, our model explains a small percentage of the variation in board gender diversity. This can be explained by our inability to consider all traits of male directors due to limited space, time and information. For example, we did not investigate educational background, which is an important demographic trait of board directors (Wiersema \& Bantel, 1992). This variable was very difficult to measure in the French context. All individual French businesspeople pursue an important number of different degrees. It is common, for example, to obtain an engineering degree, and then to continue with an MBA and a PhD or a second degree. Tracing individuals' educational background is a complex process.

The results of this study open avenues for future research from a socialized perspective. It illustrates the need for a more complex model of the antecedents of WOCB, with other trait variables of male board directors, such as nationality, experience, skills, and educational background. Our study needs to be replicated with other samples, for example from small and medium-sized firms, to understand the antecedents of WOCB among different kinds of companies. 


\section{References}

Adams, R. B., \& Ferreira, D. 2009. Women in the boardroom and their impact on governance and performance. Journal of Financial Economics, 94(2): p. 291-309.

Ahern, K. R., \& Dittmar, A. K. 2012. The changing of the boards: The impact on firm valuation of mandated female board representation. Quarterly Journal of Economics, 127(1): p. 137-197.

Allison, P. D. 1978. Measures of Inequality. American Sociological Review, 43(6): p. 865-880.

Andersen, E. B. 1970. Asymptotic properties of conditional maximum-likelihood estimators. Journal of the Royal Statistical Society. Series B (Methodological), 32(2): p. 283-301.

BAnTEL, K. A., \& JACKson, S. E. 1989. Top management and innovations in banking: Does the composition of the top team make a difference? Strategic Management Journal, 10(Supplement 1): p. $107-124$.

Becker, G. S. 1964. Human capital: a theoretical and empirical analysis, with special reference to education. New York: Columbia University Press.

Bilimoria, D., \& Piderit, S. K. 1994. Board committee membership: Effects of sex-based bias. Academy of Management Journal, 37(6): p. 1453-1477.

BLAU, P. M. 1977. Inequality and heterogeneity: a primitive theory of social structure. New York: Collier Macmillan.

Boone, C., van Olffen, W., van Witteloostuijn, A., \& De BRABANDER, B. 2004. The genesis of top management team diversity: Selective turnover among top management teams in Dutch newspaper publishing, 1970-94. Academy of Management Journal, 47(5): p. 633-656.

Bourdieu, P. 1996. The state nobility: elite schools in the field of power. Stanford: Stanford University Press.

Burgess, Z., \& Tharenou, P. 2002. Women board directors: Characteristics of the few. Journal of Business Ethics, 37(1): p. 39-49.

Byrne, D. E. 1971. The attraction paradigm. New York: Academic Press.

Carlsson, G., \& Karlsson, K. 1970. Age, cohorts and the generation of generations. American Sociological Review, 35(4): p. 710-718.

Chatterjee, S., \& HAdi, A. S. 2012. Regression analysis by example. Hoboken, N.J.: Wiley-Interscience.

Daily, C. M., Certo, S. T., \& Dalton, D. R. 1999. A decade of corporate women: Some progress in the boardroom, none in the executive suite. Strategic Management Journal, 20(1): p. 93.

Dang, R., Bender, A.-F., \& Scotto, M.-J. 2014. Women on French corporate board of directors: How do they differ from their male counterparts? Journal of Applied Business Research, 30(2): p. 489-507.

FAma, E. F., \& Jensen, M. C. 1983. Separation of ownership and control. Journal of Law and Economics, 26(2): p. 301-326.

Frank, K. A., \& Yasumoto, J. Y. 1998. Linking action to social structure within a system: social capital within and between subgroups. American Journal of Sociology, 104(3): p. 642-686.

Golden, B. R., \& Zajac, E. J. 2001. When will boards influence strategy? Inclination $\times$ power $=$ strategic change. Strategic Management Journal, 22(12): p. 1087-1111.
Gregorič, A., Oxelheim, L., Randøy, T., \& Thomsen, S. 2009. Corporate governance as a source of competitiveness for Nordic firms. Nordic Council of Ministers.

Gregorič, A., Oxelheim, L., Randøy, T., \& Thomsen, S. 2015. Resistance to change in the corporate elite: Female directors' appointments onto Nordic boards. Journal of Business Ethics: p. $1-21$.

Hambrick, D. C., Cho, T. S., \& Chen, M.-J. 1996. The influence of top management team heterogeneity on firms' competitive moves. Administrative Science Quarterly, 41(4): p. 659-684.

Hambrick, D. C., \& Mason, P. A. 1984. Upper echelons: The organization as a reflection of its top managers. Academy of Management Review, 9(2): p. 193-206.

Helfat, C. E., Harris, D., \& Wolfson, P. J. 2006. The pipeline to the top: Women and men in the top executive ranks of US corporations. Academy of Management Perspectives, 20(4): p. $42-64$.

Hillman, A. J., Cannella, A. A., \& Harris, I. C. 2002. Women and racial minorities in the boardroom: How do directors differ? Journal of Management, 28(6): p. 747-763.

Hillman, A. J., \& Dalziel, T. 2003. Boards of directors and firm performance: Integrating agency and resource dependence perspectives. Academy of Management Review, 28(3): p. 383-396.

Hillman, A. J., Shropshire, C., \& Cannella, A. A., Jr. 2007. Organizational predictors of women on corporate boards. Academy of Management Journal, 50(4): p. 941-952.

Huse, M. 2005. Accountability and creating accountability: A framework for exploring behavioural perspectives of corporate governance. British Journal of Management, 16(s1): p. S65-S79.

JANIS, I. L. 1972. Victims of groupthink: a psychological study of foreign-policy decisions and fiascoes Boston, Mass.

Johnson, S., Schnatterly, K., Bolton, J. F., \& Tuggle, C. 2011. Antecedents of new director social capital. Journal of Management Studies, 48(8): p. 1782-1803.

Johnson, S. G., Schnatterly, K., \& Hill, A. D. 2013. Board composition beyond independence: Social capital, human capital, and demographics. Journal of Management, 39(1): p. 232-262.

Kadushin, C. 1995. Friendship among the French financial elite. American Sociological Review, 60(2): p. 202-221.

Kang, H., Cheng, M., \& Gray, S. J. 2007. Corporate governance and board composition: Diversity and independence of Australian boards. Corporate Governance: An International Review, 15(2): p. 194-207.

Kanter, R. M. 1977. Men and women of the Corporation. New York: Basic Books.

Katz, R. 1982. The Effects of Group Longevity on Project Communication and Performance. Administrative Science Quarterly, 27(1): p. 81-104.

Kesner, I. F. 1988. Directors' characteristics and committee membership: An investigation of type, occupation, tenure, and gender. Academy of Management Journal, 31(1): p. 66-84.

Labelle, R., Francoeur, C., \& Lakhal, F. 2015. To regulate or not to regulate? Early evidence on the means used around the world to promote gender diversity in the boardroom. Gender, Work \& Organization, 22(4): p. 339-363. 
LIU, Y., WEI, Z., \& XIE, F. 2014. Do women directors improve firm performance in China?. Journal of Corporate Finance, 28(October): p. 169-184.

Maclean, M., Harvey, C., \& Chia, R. 2010. Dominant corporate agents and the power elite in France and Britain. Organization Studies, 31(3): p. 327-348.

Michel, J. G., \& Hambrick, D. C. 1992. Diversification posture and top management team characteristics. Academy of Management journal, 35(1): p. 9-37.

Moulin, Y., \& Point, S. 2012. Les femmes dans les conseils d'administration du SBF 120: qualités féminines ou affaires de famille? Revue de Gestion des Ressources Humaines, 83(1): p. 31-44.

Nekhili, M., \& Gatfaoui, H. 2013. Are demographic attributes and firm characteristics drivers of gender diversity? Investigating women's positions on French boards of directors. Journal of Business Ethics, 118(2): p. 227-249.

Nguyen, D. B. 2012. Does the rolodex matter? Corporate elite's small world and the effectiveness of boards of directors. Management Science, 58(2): p. 236-252.

Pfeffer, J. 1972. Size and composition of corporate boards of directors: The organization and its environment. Administrative science quarterly, 17(2): p. 218-228.

Pfeffer, J. 1983. Organizational demography. In L. L. Cummings, \& B. M. Staw (Eds.), Research in Organizational Behavior: p. 299-357. Greenwich: JAI Press.

Pfeffer, J., \& Salancik, G. R. 1978. The external control of organizations: A resource dependence perspective. New York: Harper \& Row.

Pitcher, P., \& Smith, A. D. 2001. Top management team heterogeneity: Personality, power, and proxies. Organization Science, 12(1): p. 1-18.

Ployhart, R. E., Weekley, J. A., \& Baughman, K. 2006. The structure and function of human capital emergence: A multilevel examination of the attraction-selection-attrition model. Academy of Management Journal, 49(4): p. 661-677.

Quinn, R. E., \& Cameron, K. 1983. Organizational Life Cycles and Shifting Criteria of Effectiveness: Some Preliminary Evidence. Management Science, 29(1): p. 33-51.

Schmidt, W. H., \& Posner, B. 1983. Managerial Values in Perspective. New York: Amacom Books.

SCHNEIDER, B. 1983. Interactional psychology and organizational behavior. In L. L. Cummings (Ed.), Research in organizational behavior: p. 1-31. Greenwich, CT: JAI Press.

Schneider, B. 1987. The people make the place. Personnel Psychology, 40(3): p. 437-453.

Singh, V., Terjesen, S., \& Vinnicombe, S. 2008. Newly appointed directors in the boardroom: How do women and men differ? European Management Journal, 26(1): p. 48-58.
Smith, N., Smith, V., \& Verner, M. 2006. Do Women in Top Management Affect Firm Performance?A Panel Study of 2,500 Danish Firms. International Journal of Productivity and Performance Management, 55(7): p. 569-593.

Stangor, C., Lynch, L., Duan, C., \& Glas, B. 1992. Categorization of Individuals on the Basis of Multiple Social Features. Journal of Personality and Social Psychology, 62(2): p. 207-218.

STAW, B. M. 1977. Motivation in organizations: Toward synthesis and redirection. In B. M. Staw, \& G. R. Salancik (Eds.), New directions in organizational behavior: p. 55-95. Chicago: St. Clair Press.

Staw, B. M., \& Ross, J. 1980. Commitment in an Experimenting Society: A Study of the Attribution of Leadership from Administrative Scenarios. Journal of Applied Psychology, 65(3): p. 249-260.

Tajfel, H., \& Turner, J. C. 1986. The social identity of intergroup relations. In S. Worchel, \& W. G. Austin (Eds.), Psychology of intergroup relations: p. 7-24. Chicago: Nelson-Hall.

Terjesen, S., Sealy, R., \& Singh, V. 2009. Women directors on corporate boards: A review and research agenda. Corporate Governance: An International Review, 17(3): p. 320-337.

Tsui, A. S., \& O’Reilly, C. A. 1989. Beyond simple demographic effects: The importance of relational demography in superior-subordinate dyads. Academy of Management Journal, 32(2): p. $402-423$.

Tushman, M. L., \& Romanelli, E. 1985. Organizational Evolution: A Metamorphosis Model of Convergence and Reorientation. In B. M. Staw, \& L. L. Cummings (Eds.), Research in organizational behavior 7: p. 171-222. Greenwich, Conn.: JAI Press.

Useem, M., \& KarabeL, J. 1986. Pathways to top corporate management. American Sociological Review: p. 184-200.

Vroom, V. H., \& PAHL, B. 1971. Relationship between age and risk taking among managers. Journal of Applied Psychology, 55(5): p. 399 .

Wagner, W. G., Pfeffer, J., \& O’Reilly III, C. A. 1984. Organizational demography and turnover in top-management group. Administrative Science Quarterly, 29(1): p. 74-92.

Westphal, J. D., \& Stern, I. 2006. The other pathway to the boardroom: Interpersonal influence behavior as a substitute for elite credentials and majority status in obtaining board appointments. Administrative Science Quarterly, 51(2): p. 169-204.

Wiersema, M. F., \& Bantel, K. A. 1992. Top management team demography and corporate strategic change. Academy of Management Journal, 35(1): p. 91-121.

Williamson, O. E. 1984. Corporate Governance. Yale Law Review, 93(1): $1197-1230$

Withers, M. C., Hillman, A. J., \& Cannella, A. A. J. 2012. A multidisciplinary review of the director selection literature. Journal of Management, 38(1): 243-277. 